\title{
Aerial Gamma Survey by Helicopter to Measure Surficial Contamination
}

\author{
L. E. Bruns
}

March 1975

Prepared for the U. S. Energy Research and Development Administration Under Contract AT (45-1) $=2130$

Atlantic Richfield Hanford Company Richland, Washington 99352
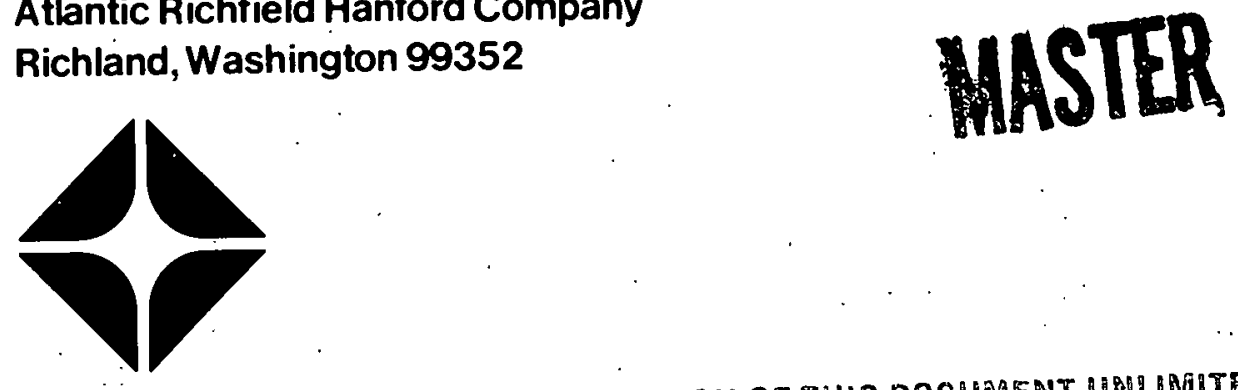


\section{DISCLAIMER}

This report was prepared as an account of work sponsored by an agency of the United States Government. Neither the United States Government nor any agency Thereof, nor any of their employees, makes any warranty, express or implied, or assumes any legal liability or responsibility for the accuracy, completeness, or usefulness of any information, apparatus, product, or process disclosed, or represents that its use would not infringe privately owned rights. Reference herein to any specific commercial product, process, or service by trade name, trademark, manufacturer, or otherwise does not necessarily constitute or imply its endorsement, recommendation, or favoring by the United States Government or any agency thereof. The views and opinions of authors expressed herein do not necessarily state or reflect those of the United States Government or any agency thereof. 


\section{DISCLAIMER}

Portions of this document may be illegible in electronic image products. Images are produced from the best available original document. 


\section{Atlantic Richfield Hanford Company Richland, Washington 99352}

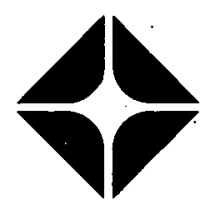

PREPARED FOR THE U.S. ENERGY RESEARCH AND DEVELOPMENT ADMINISTRATION UNDER CONTRACT AT (45-1) 2130

\section{PRELIMINARY REPORT}

THIS REPORT CONTAINS INFORMATION OF A PRELIMINARY NATURE. IT IS SUBJECT TO REVISION OR CORRECTION AND THEREFORE DOES NOT REPRESENT A FINAL REPORT. IT WAS PREPARED PRIMARILY FOR INTERNAL USE WITHIN THE ATLANTIC RICHFIELD HANFORD COMPANY. ANY EXPRESSED VIEWS AND OPINIONS ARE THOSE OF THE AUTHOR AND NOT NECESSARILY OF THE COMPANY.

\section{NOTICE}

THIS REPORT WAS PREPARED AS AN ACCOUNT OF WORK SPONSORED EY THE UNITED STATES GOVERNMENT. NEITHER THE UNITED STATES NOR THE UNITED STATES ENERGY RESEARCH AND DEVELOPMENT ADMINISTRATION, NOR ANY OF THEIR EMMPLOYEES. NOR ANY OF THEIR CONTRACTORS. SUBCONTRACTORS. OR THEIR EMPLOYEES, MAKES ANY WARRANTY, EXPRESS OR IMPLIED, OR ASSUMES ANY LEGAL LIABILITY OR RESPONSIBILITY FOR THE ACCURACY, COMPLETENESS OR USEFULNESS OR ANY INFORḾMATION, APPARATUS, PRODUCT OR PROCESS DISCLOSED, OR REPRESENTS THAT ITS USE WOULD NOT INFRINGE PRIVATELY OWNED RIGHTS. 
AERIAL GAMMA. SURVEY BY HELICOPTER

TO MEASURE SURFICIAL CONTAMINATION

\author{
L. E. Bruns
}

Research and Engineering

Research Department

Physical and Life Science Technology

March 1975

\title{
ATLANTIC RICHFIELD HANFORD COMPANY
}

RICHLAND, WASHINGTON

\section{- NOTICE}

This report was prepared as an account of work This report was prepared ates Government. Neither sponsored by the United States Government the United States nor the United States Energy Research and Development Administration, nor any of their employees, nor any of their contractors, their employees, makes any subcontractors, or thimplied, or assumes any legal warranty, express or implied, or assumes anpleteness liability or responsibility for the accuracy, completeness or usefulness of any information, apparatus, product or process disclosed, or represents that its use would not infringe privately owned rights. 


\section{ABSTRACT}

A development project was sponsored by Atlantic Richfield Hanford Company to determine whether aerial gamma surveys could adequately measure the activity of high specific activity gamma emitters contaminating large surface areas. The survey successfully measured the ${ }^{137}$ Cs activity and the total gross gamma over areas from less than 1 to $20 \mathrm{~km}^{2}$. Also, ${ }^{241}$ Am was successfully measured over areas wherein the ${ }^{137} \mathrm{Cs}$ was sufficiently low. Micro-curies per $\mathrm{m}^{2}$ were measured as low as 0.1 for ${ }^{137} \mathrm{Cs}$ and ${ }^{241} \mathrm{Am}$. Other radionuclides such as ${ }^{60}$ Co were also detected. An aerial neutron survey was tried, though its efficiency limited detection to areas having more than $10 \mathrm{~kg}$ Pu per $4,000 \mathrm{~m}^{2}$. The aerial survey can analyze a complete area, thereby saving millions of dollars in statistical sampling and analytical programs.

Key Words for Indexing:

radioactivity gamma survey remote-sensing surficial contamination aerial hel icopter 
AERIAL GAMMA SURVEY BY HEL ICOPTER

TO MEASURE SURFICIAL CONTAMINATION

INTRODUCTION

In over $30 \mathrm{yr}$, contractors for the Energy Research and Development Administration at Hanford have operated 9 reactors and have initiated and operated on a production scale the Bismuth Phosphate, Redox, and the Purex nuclear fuel chemical separation processes. Also a process to recover the uranium from Bismuth Phosphate waste, a plutonium nitrate to metal plant, a weapons fabrication facility, and two scrap recovery processes were operated. Radioactive waste was imported from other sites for processing or interim storage. From all this and extensive laboratory experiments, considerable waste was generated for interim storage throughout an area at Hanford called the 200 Areas Plateau, an excellent storage environment due to the favorable geological characteristics, i.e., water table at 250 feet, reverse sub-surface moisture flow hence bulk of rainfall moisture in top seven meters and the soil has excellent uptake of radionuclịdes via ion exchange mechanisms, filtration, etc.

Wastes generated at Hanford or offsite were classified as high-level waste (arbitrarily set at wastes greater than $100 \mu \mathrm{Ci} / \mathrm{g}$ waste material, e.g., Purex-solvent extraction waste); intermediate level waste (between $5 \times 10^{-5}$ and $100 \mu \mathrm{Ci} / \mathrm{g}$ waste, e.g., evaporator overheads); and low level waste (less than $5 \times 10^{-5} \mu \mathrm{Ci} / \mathrm{g}$ waste, e.g., cooling water). Only low-level wastes will be considered in this report.

Low-level waste locations are divided into two categories - planned (e.g., ponds) and unplanned releases (e.g., plant uptake). These surficial wastes are under close surveillance due to their resuspension potential and their availability to plants and animals. An 
initial need to help assure public safety is to characterize the waste as to concentrations of activity on the surface as well as in depth to root levels. Considering the large areas to cover and the number of samples required for statistically accurate results, a development project was proposed involving measuring the overall gamma activity by use of a helicopter.

Helicopters have been tried by the EG\&G Company of Las Vegas as part of the Aerial Radiological Measuring System (ARMS) program for ERDA. A development program was planned by the Atlantic Richfield Company (ARHCO) with assistance from ERDA.

\section{SUMMARY}

Key areas containing potential surficial radioactivity contamination were gamma assayed by use of $\mathrm{NaI}(\mathrm{Tl})$ 5-in. diam crystals mounted in pods on either side of a Sikorsky SH-3 helicopter. Total gamma, ${ }^{137} \mathrm{Cs}$, and in one case, ${ }^{241}$ Am were obtained and displayed on isodose and isoactivity charts. Interpretation of results showed the BC Crib (See Fig. 1) to have about $5 \mathrm{Ci}$ of ${ }^{137} \mathrm{Cs}$ on the surface while the U Pond (See Fig. 1) had about $25 \mathrm{Ci}$ of ${ }^{137} \mathrm{Cs}$. Tests for ${ }^{241} \mathrm{Am}$ on the $U$ Pond were nullified by the Compton scattering; however, results were obtained on the ditch from the Plutonium Finishing Plant to the U Pond.

\section{PREPARATION FOR SURVEY.}

Areas were selected by ARHCO on the 200 Areas Plateau for a development survey. Figure 1 shows the areas (marked by heavy lines) designated for 
the gamma survey. Figure 2 is a picture of the SH-3 Sikorsky helicopter used in the ARHCO tests. The areas were ground-surveyed and marked off in $150-\mathrm{ft}$ grids for ${ }^{137} \mathrm{Cs}$ and $100-\mathrm{ft}$ grids for ${ }^{241} \mathrm{Am}$.

The $B C$ Crib area and the $U$ Pond were chosen for initial study. Others in the study were the Redox Swamp, B Pond, Gable Mountain Pond north of the 200 East Area, T Pond, and the Redox Area (See Figure 1). The latter two were covered with only two passes. The others were ground-surveyed with each area being marked to enable complete gridded helicopter coverage. In the $B C$ Crib area, large plastic white crosses were placed at key points for easier relation of grid lines to the overall area.

Initial helicopter maneuvers involved photographing the areas to be surveyed and calibrated. Mosaics were made of the photographs for each area and became the base for overlays of transparencies which contained isodose and isoactivity lines. Advantage was taken of initial EG\&G calibrations plus calibrations performed at Hanford. White plastic crosses, carefully distanced, were laid out in a typical desert area. From these, angular response calibrations were made. Calibrations were also made on ground concentration versus counts per minutes of the instrument. Factors such as air attenuation and scattering were considered. The activity on the ground was assumed to be surface activity. 
THE AREAS

The two areas chosen as mentioned previously were the BC Crib area, an unplanned release, and the $U$ Pond area, a planned release. The unplanned release originated in an area south of the 200 East Plateau (See Figure 1). Originally, many trenches were filled with supernatants from a precipitation process carried out in the 200 East Area waste tanks. The waste originated from the U Plant solvent extraction waste. The U Plant used a $25 \%$ tributylphosphate (TBP) in a light hydrocarbon diluent and recovered $U$ from the Bismuth Phosphate waste. The resulting U Plant waste was so voluminous and costly to store that a new process was developed at the tank farm to minimize the volume of waste.

A nickel ferrocyanide process was used which precipitated out the bulk of the ${ }^{90} \mathrm{Sr}$ and ${ }^{137} \mathrm{Cs}$. The precipitate stayed in the high-level waste tanks and the supernatant went to the $B C$ Crib in what is termed specific retention trenches. When the trench soil had reached liquid saturation levels another trench was used. Trenches covering about 15 acres were required before the U Plant processing was complete. The trenches are about four meters deep.

An animal, probably a badger, managed to burrow into the crib area and a salt cake was discovered by the rabbits about 1959: The result was a contamination spread over about four square miles from rabbit and coyote (coyotes ate the rabbits) excrements. In 1964 the contamination was 
discovered and the trenches, initially covered with soil, were covered over with gravel and aslphalt to prevent further subsurface entry
by animals.

The $U$ Pond received low level waste from the Plutonium Finishing Plant, Plutonium Scrap Recovery Plants, Analytical and Development Laboratories, the experimental Plutonium Metal Facility (now Battelle Pacific Northwest Laboratories' 231 Building), the U Plant. Process and the laundry. - It covers about 25 acres and varies in depth from less than $15 \mathrm{~cm}$ to about one $\mathrm{m}$ deep. After startup back in the early 1950's, the pond volume soon reached equilibrium and the estimated concentration factor from then to now is about 200 .

\section{RESULTS}

The EG\&G report entitled "Hanford Survey" May 22 to June 6., 1973," discussed the calibrations and showed the isodose and isoactivity charts considered in the development study. Two of them will be discussed in detail--the $\mathrm{BC}$ Crib and the $U$ Pond.

$\underline{B C \text { Crib }}$

The total gamma between $50 \mathrm{KeV}$ and $3 \mathrm{MeV}$ is shown in Figure 3. The total gamma is due mainly to ${ }^{137} \mathrm{Cs}$; however, there was a little help from ${ }^{60} \mathrm{Co}$ and ${ }^{241} \mathrm{Am}$ and a few other isotopes. This chart compares favorably with the ${ }^{137}$ Cs map shown in Figure 4 . 
Both charts show that the isodose lines were. weighted heavier downwind. This may change more rapidly with time since the rabbit pellets were beginning to deteriorate into dust. Laboratory tests have shown that the radionuclides can also leach to some extent with time. Periodic helicopter surveys may indicate these and other changes with time. Current routine surveillance activities (includes aerial surveys) along with resuspension, further leaching, plant uptake and other studies will assure continued control of the area. Besides this, fixation agents are available for surface immobilization.

Measurements from above the ground nondestructive assay units must consider activity in the subsurface. Calibrations are based on surface activity with no correction for subsurface activity. For final interpretation of results, in-depth radioactivity profiles were obtained in spots throughout the BC Crib area.

The attenuation coefficient, $\mu$, for soil is estimated to be 0.15 . Using this, the half-thickness, or depth of soil to reduce the activity $50 \%$ is $7.5 \mathrm{~cm}$. Depth analyses showed the bulk of the activity to be in the top $10 \mathrm{~cm}$. Also, by laboratory analyșes strontium-to-cesium ci ratios were established. This gives overall results from the aerial survey and laboratory analyses as observed in Tables 1 and 2 .

Laboratory analyses showed the presence of many more radionuclides but none of sufficient magnitude to significantly increase the $96 \mathrm{Ci}$. The $96 \mathrm{Ci}$ are considered to be on the high side since (1) the high side is favored on 
analyses variations for conservation and (2) the activity from the cribs themselves may have increased the readings in the actual crib area. This - latter effect should be low since all crib contents should be down at least $100 \mathrm{~cm}$, and at $100 \mathrm{~cm}$ the activity "seen" by the helicopter is less than $0.001 \%$. Figure 5 shows a few typical ${ }^{137}$ Cs and ${ }^{90}$ Sr profiles with depth.

To corroborate the aerial survey about 6 composite samples were taken of the surface (top $5-\mathrm{cm}$ ) ranging from 10 to 100 individual samples per composite. Results to date show a comparison in the highest concentration area for ${ }^{137}$ Cs. (Table 2)

The activity distribution from the rabbits and coyotes is highly variable. Therefore to obtain a good statistical "ground truthing" hundreds of samples per acre are necessary. An approximation of the high and low areas. was estimated by a Geiger-Mueller counter which agreed with the aeriat survey.

$\underline{U}$ Pond

The $U$ Pond activity shows about $25 \mathrm{C} i$ of "equivalent" ${ }^{137} C_{\text {s surface acti- }}$ vity. Total gamma in Figure 6 shows a difference when compared with ${ }^{137} \mathrm{Cs}$ gamma shown in Figure 7. This is due to the significant presence of other gamma emitters such as ${ }^{241} \mathrm{Am},{ }^{60} \mathrm{Co}$, and others. Additional surface and subsurface laboratory analyses are required before an accurate estimate can be made of the activity spread and profile in the $U$ Pond. 
A rough estimate needs to include corrections for the water attenuation, variation of activity with depth and the activity due to high subsurface stored activity, e.g., the high-level waste tank farm area and the Z-9

crib area. Approximately $20 \%$ of the activity read by the helicopter was due to buried high-level and intermediate waste. An over-the-pond attenuation factor is taken as 3 . A depth profile study on scattered analyses adds another $50 \%$. From these, a value of $75 \mathrm{Ci}$ of ${ }^{137} \mathrm{Cs}$ on the $1.5 \times 10^{6}-m^{2}$ area is estimated. Comparison with total gamma gives a first rough estimate of total gamma $\mathrm{Ci}$ at 100.

The total dosage per year due to gamma at the $U$ Pond ranges from less than one $\mathrm{R} / \mathrm{yr}$ to $44 \mathrm{R} / \mathrm{yr}$. Spectral lines were run at both $\mathrm{BC}$ Crib and $U$ Pond areas. The $U$ Pond spectral lines showed significant ${ }^{241} \mathrm{Am}$ and ${ }^{60} \mathrm{Co}$ which agrees with the laboratory findings on soil analyses.

Americium-241 runs worked successfully over an area where cesium was a minor constituent. Figure 8 shows where ${ }^{241}$ Am could be ascertained and where the activity was masked by Cs. A value for the ${ }^{241}$ Am gives only an approximation of the Pu since the low-level effluents from the various plants often originated from locations in the processes wherein the Am and Pu had been separated. A neutron survey was tried on a subsequent helicopter survey but was not efficient enough to monitor areas like $U$ Pond. 


\section{CONCLUSION}

1. Gamma activity on the surface can be estimated within $a \pm 50 \%$ from helicopter aerial surveys. Periodic gamma surveys should help show any lateral movement of activity.

2. Total "effective" activity can be estimated using as a basis the ${ }^{137} \mathrm{Cs}$ activity by the aerial survey, total gamma activity, and laboratory analyses in the $X-Y-Z$ plane at the surface with the $Z$-values going down to $30-\mathrm{cm}$ depths or further if activity is significant.

3. Both single-channel and multi-channel readings can be taken by the helicopter. The spectrum from the multi-channel runs can give the radioactive gamma emitting species of a given area:

4. Americium can be measured from a helicopter providing higher energy gammas such as ${ }^{137}$ Cs are insignificant.

FUTURE

Since this development project was completed, two additional helicopter surveys were made. These included two further development tests, one using a $\mathrm{Ge}(\mathrm{Li})$ high resolution gamma detector system, another using a neutron detector system. Further work is required before the feasibility of these new systems can be determined; the $\mathrm{Ge}(\mathrm{L} i)$ unit requires more efficiency, the neutron unit more sensitivity. Methods for minimizing Compton scattering would be helpful and with use of these detectors and others this may be possible. The rapid progress of detectors will be closely followed and perhaps sometime soon more efficient and sensitive units will be available. 


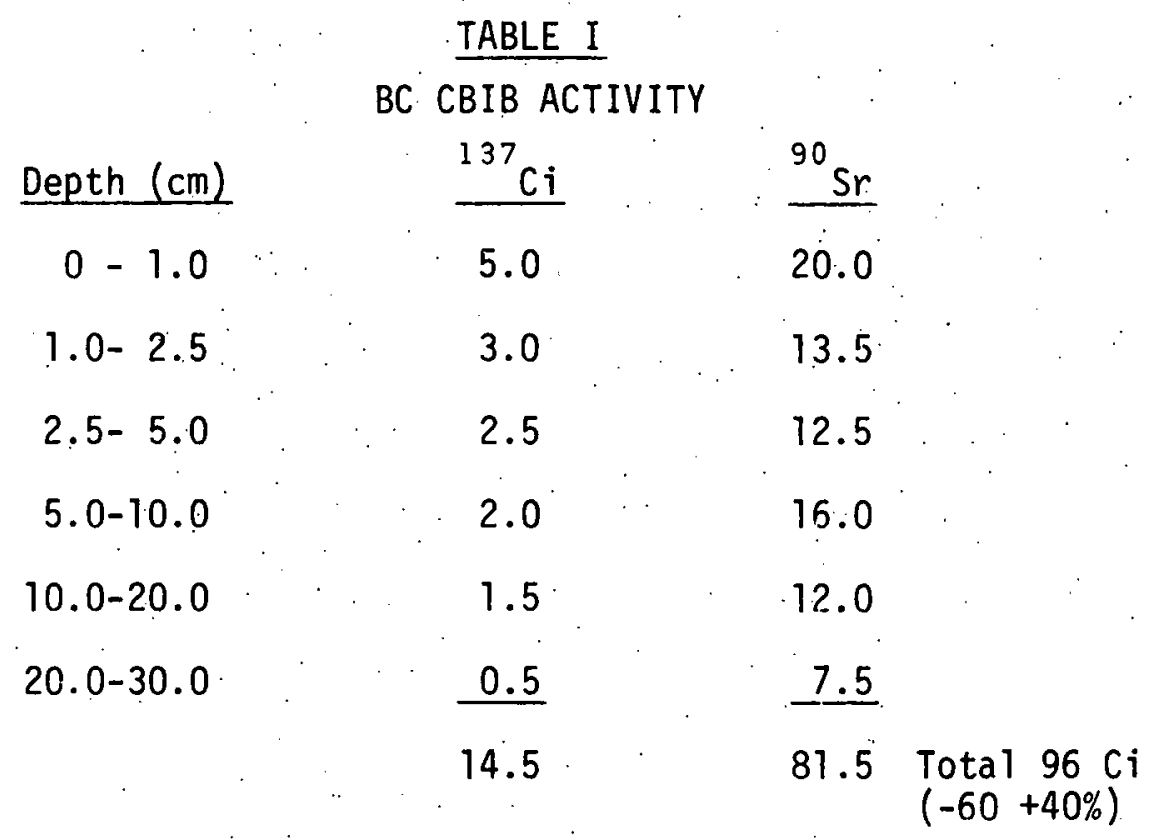


TABLE 2

AERIAL SURVEY VERSUS GROUND SAMPLING

Aerial Survey

$10 \mu \mathrm{Ci} / \mathrm{m}^{2}$
Composite Sampling

$11.5 \mu \mathrm{Ci} / \mathrm{m}^{2}$ (average) 


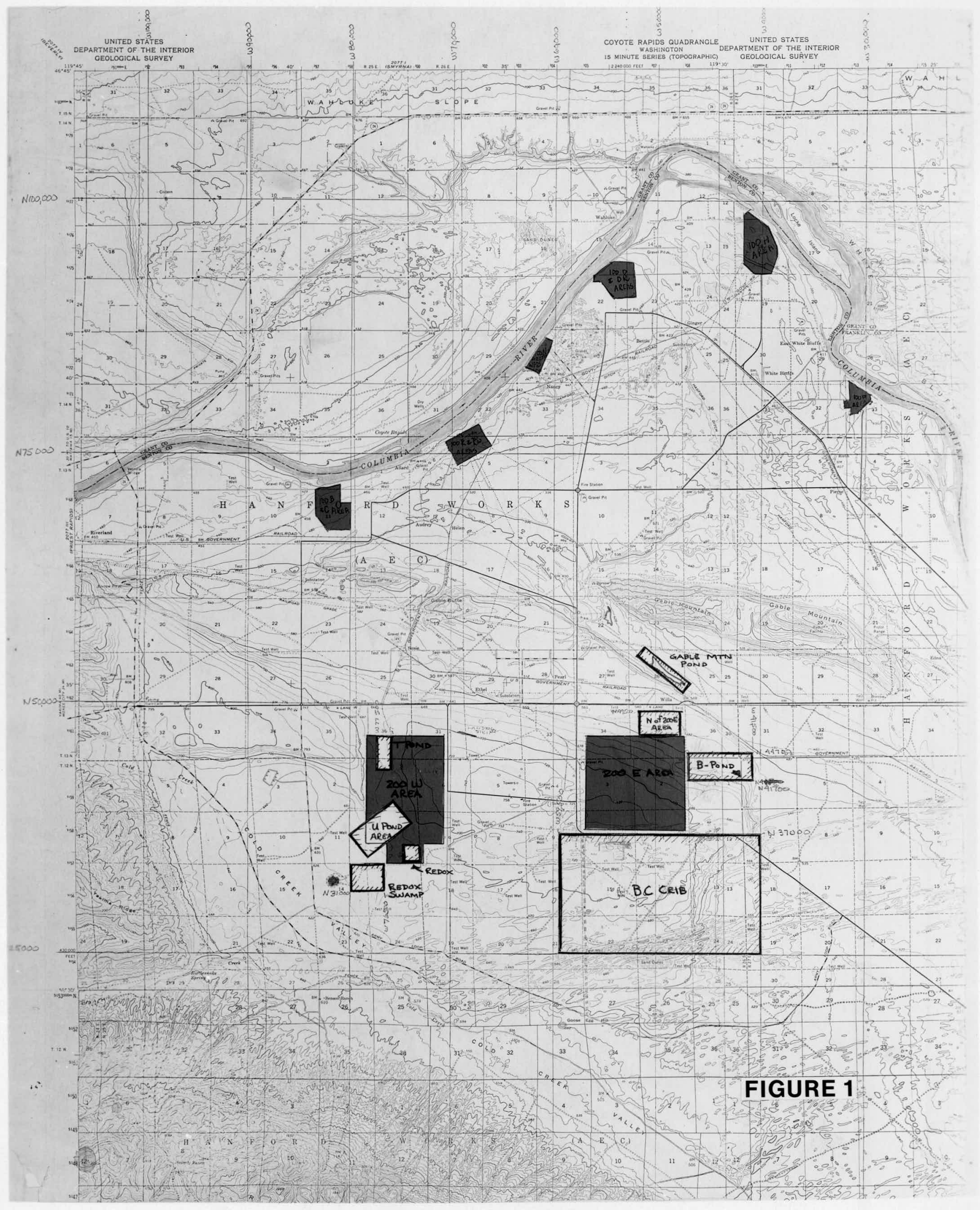




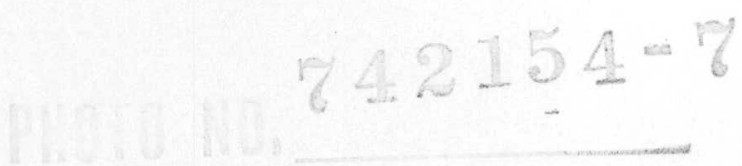

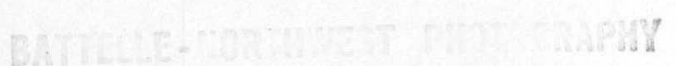

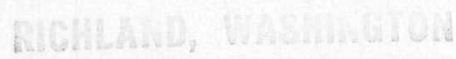

99352 


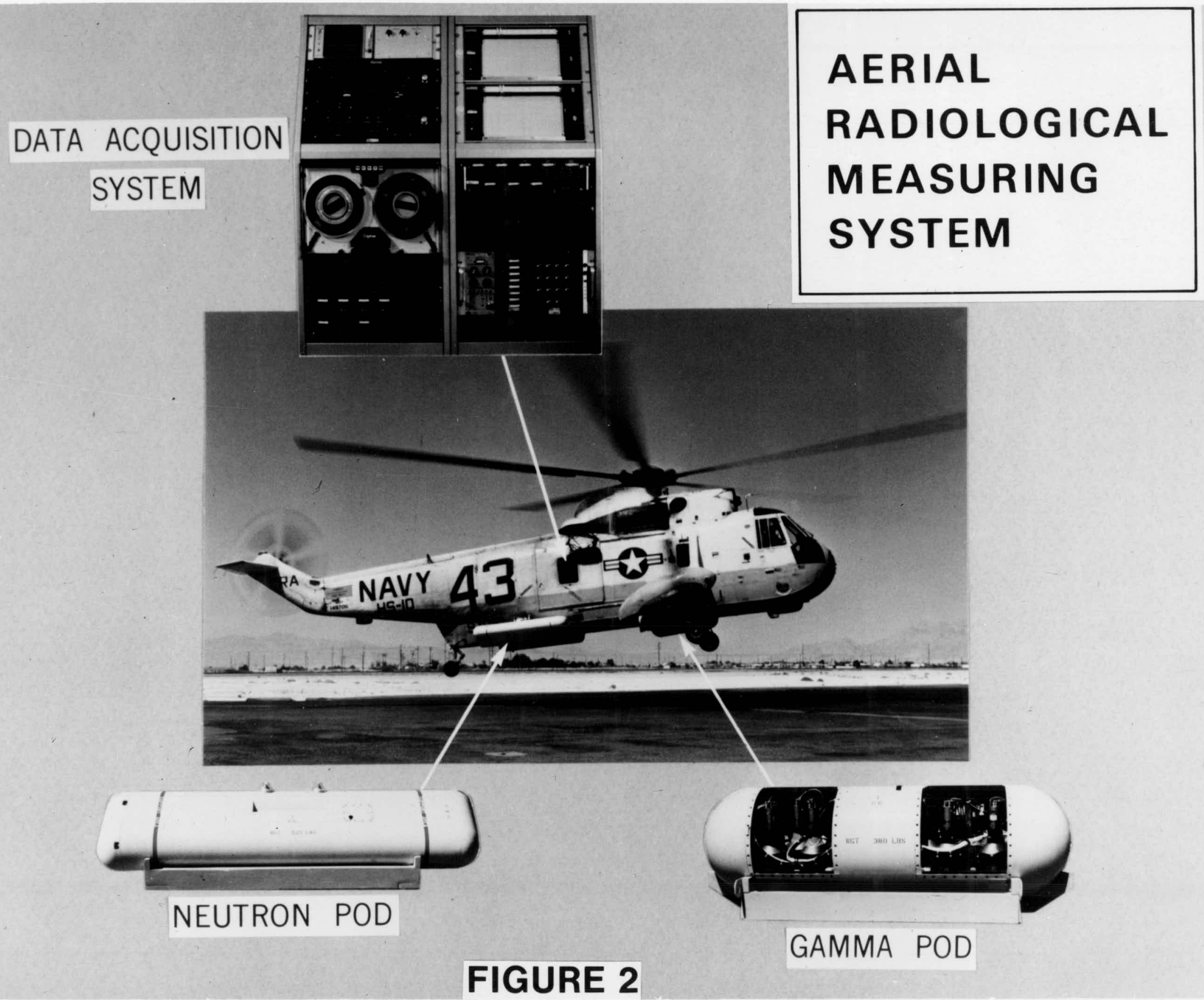


PII070 10, $\quad 633131$

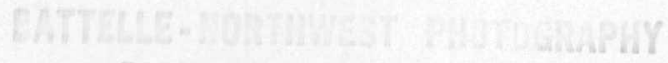

RICHLAwD, WhashaneTon

99352 


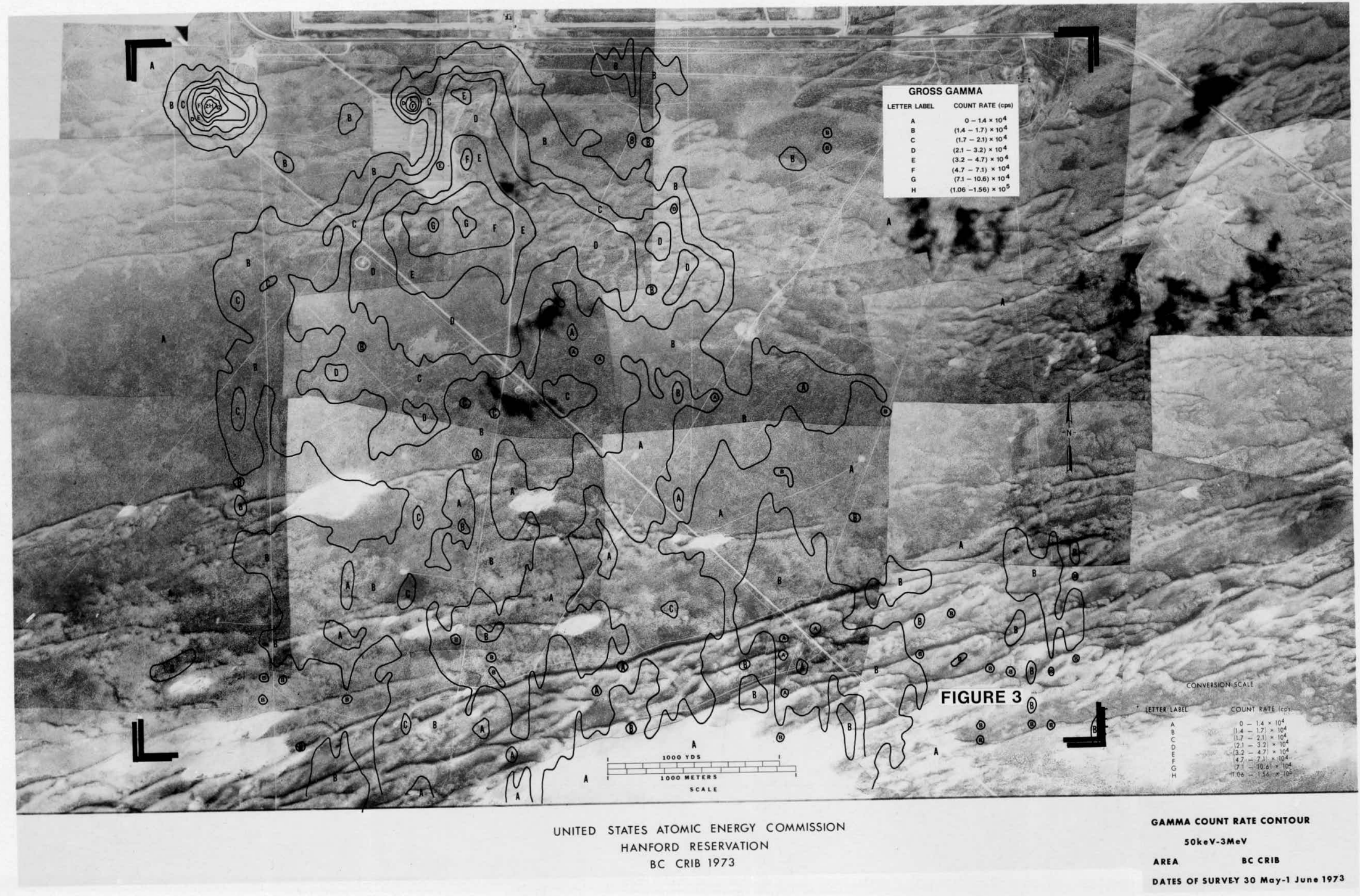




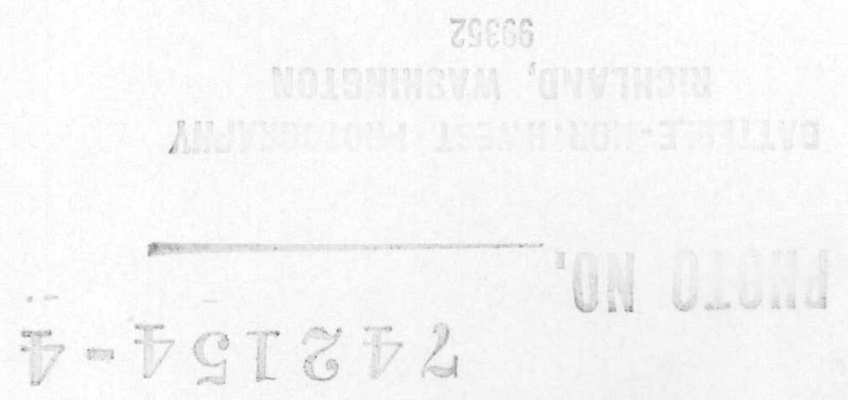




\section{$90 \%$}

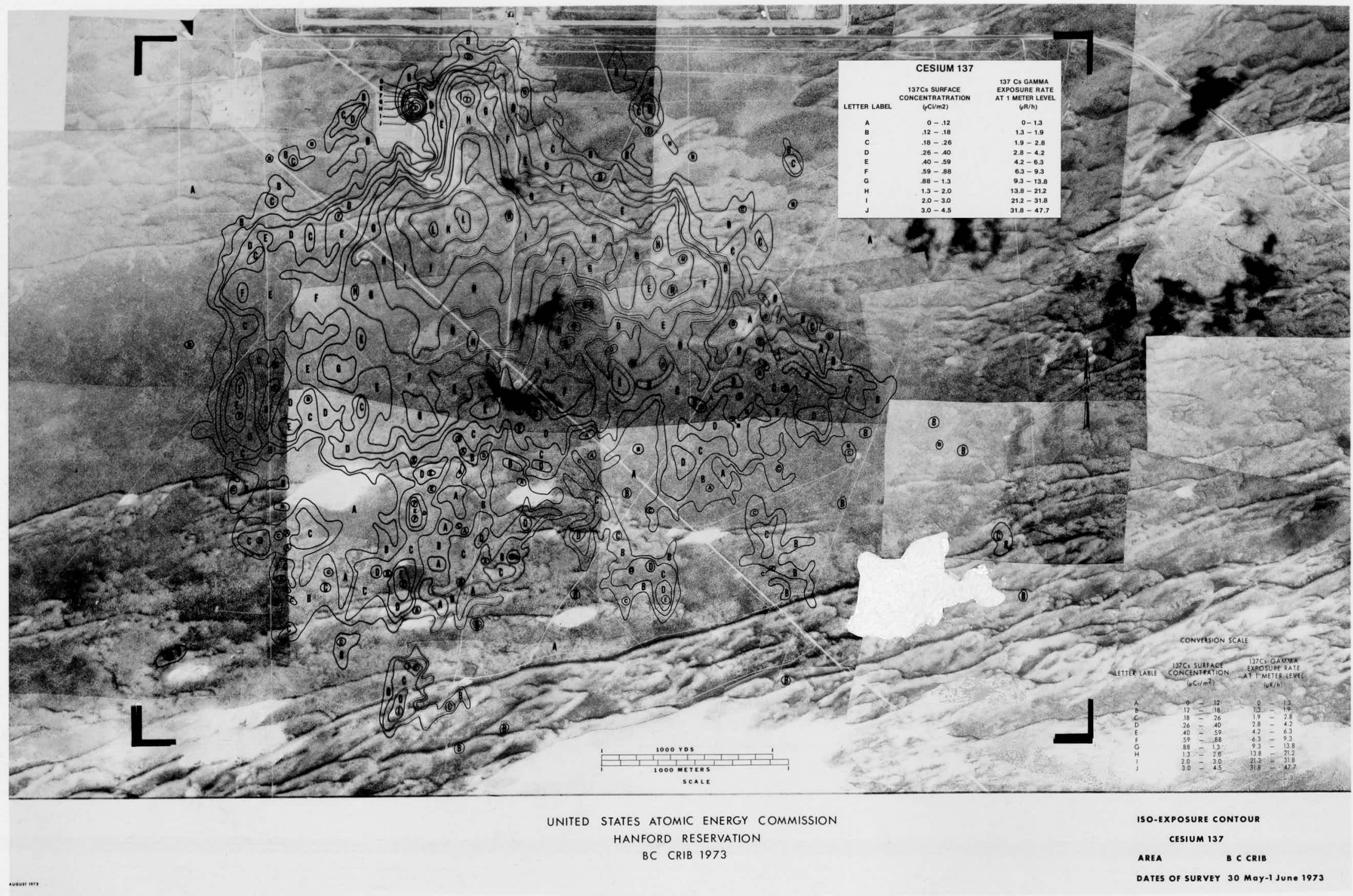

CONF-740921

${ }^{7 . g .4}$ p.6r2 


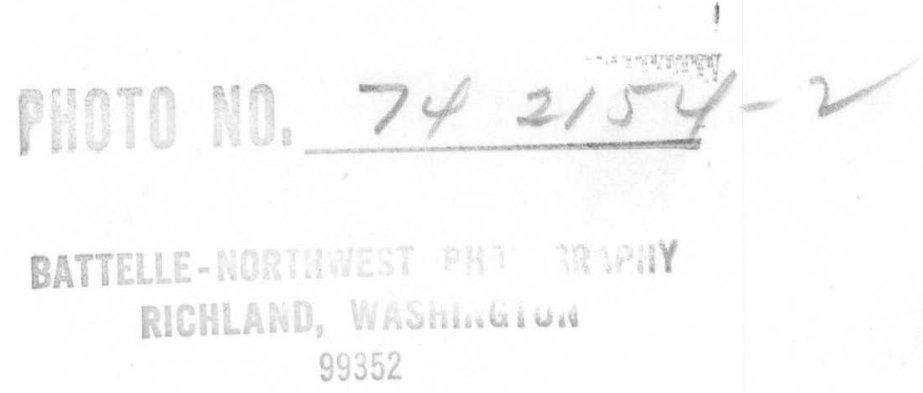


${ }^{90} \mathrm{Sr} \&{ }^{137} \mathrm{Cs}$ CONCENTRATION VS DEPTH

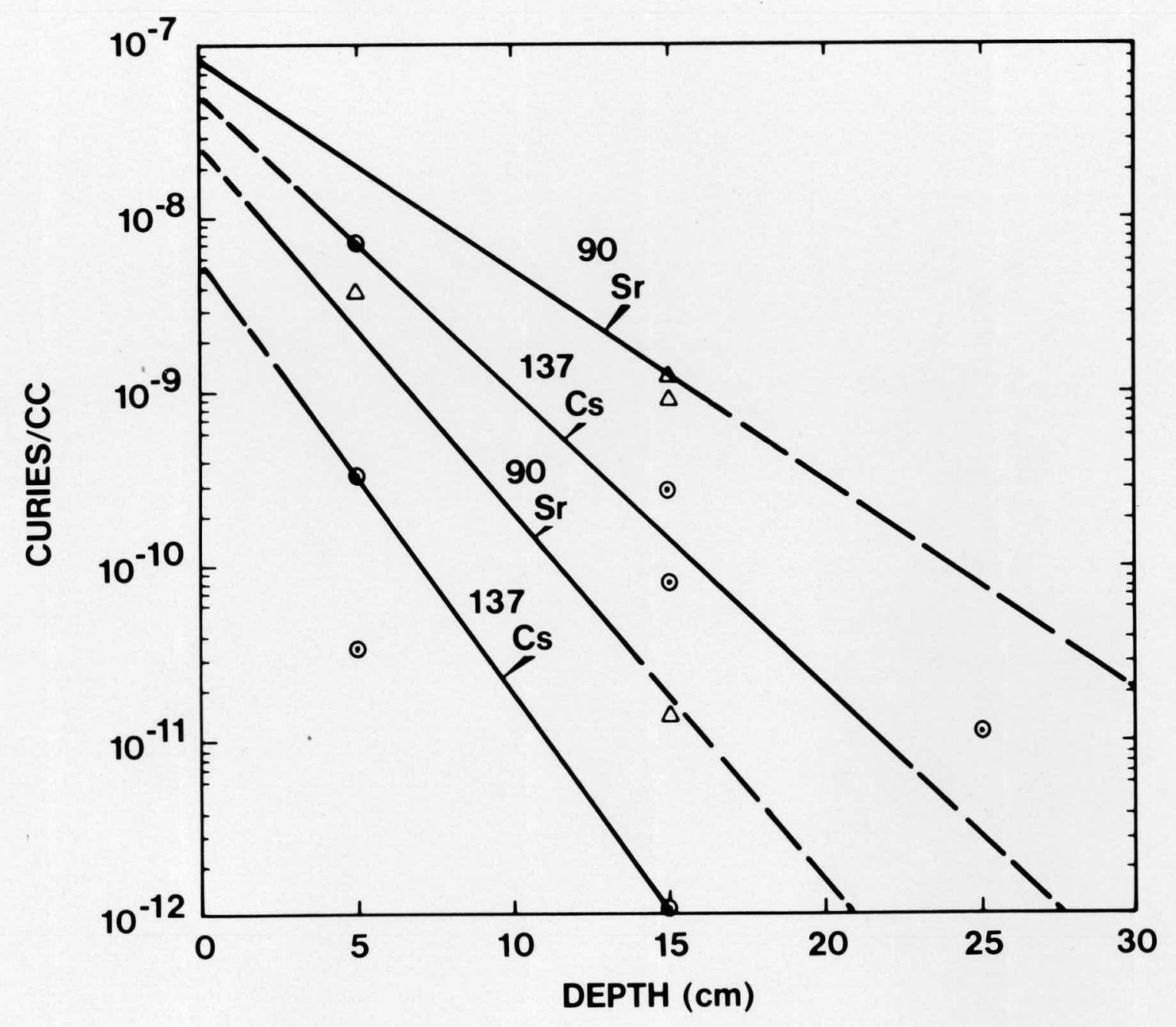

FIGURE 5 


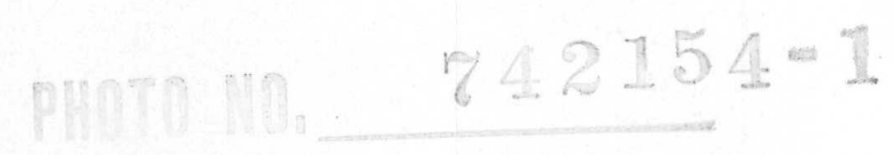

99952 


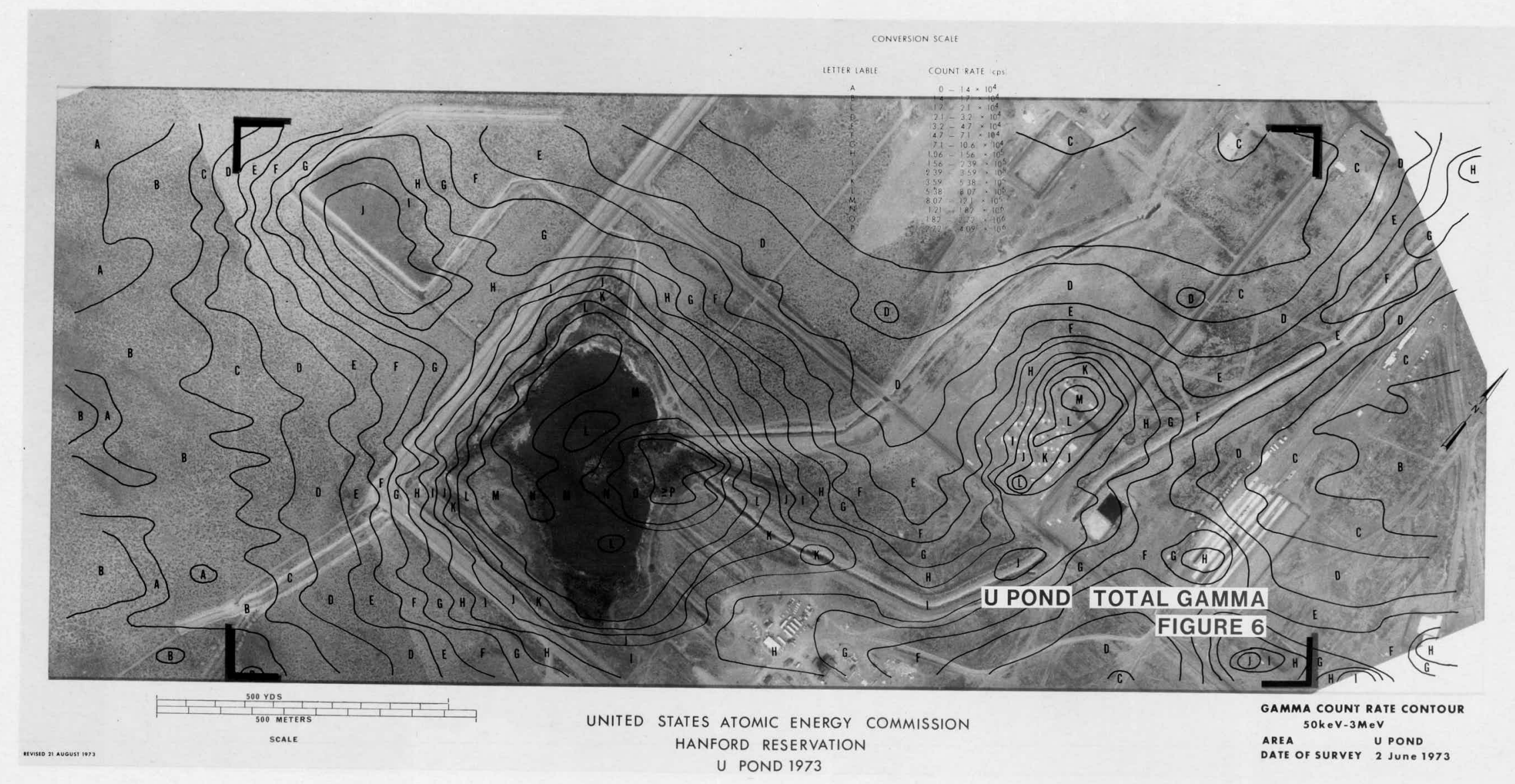


29855

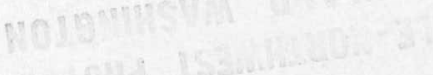

17.

S

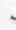

Wh: 22028

$8-79-2021$ 


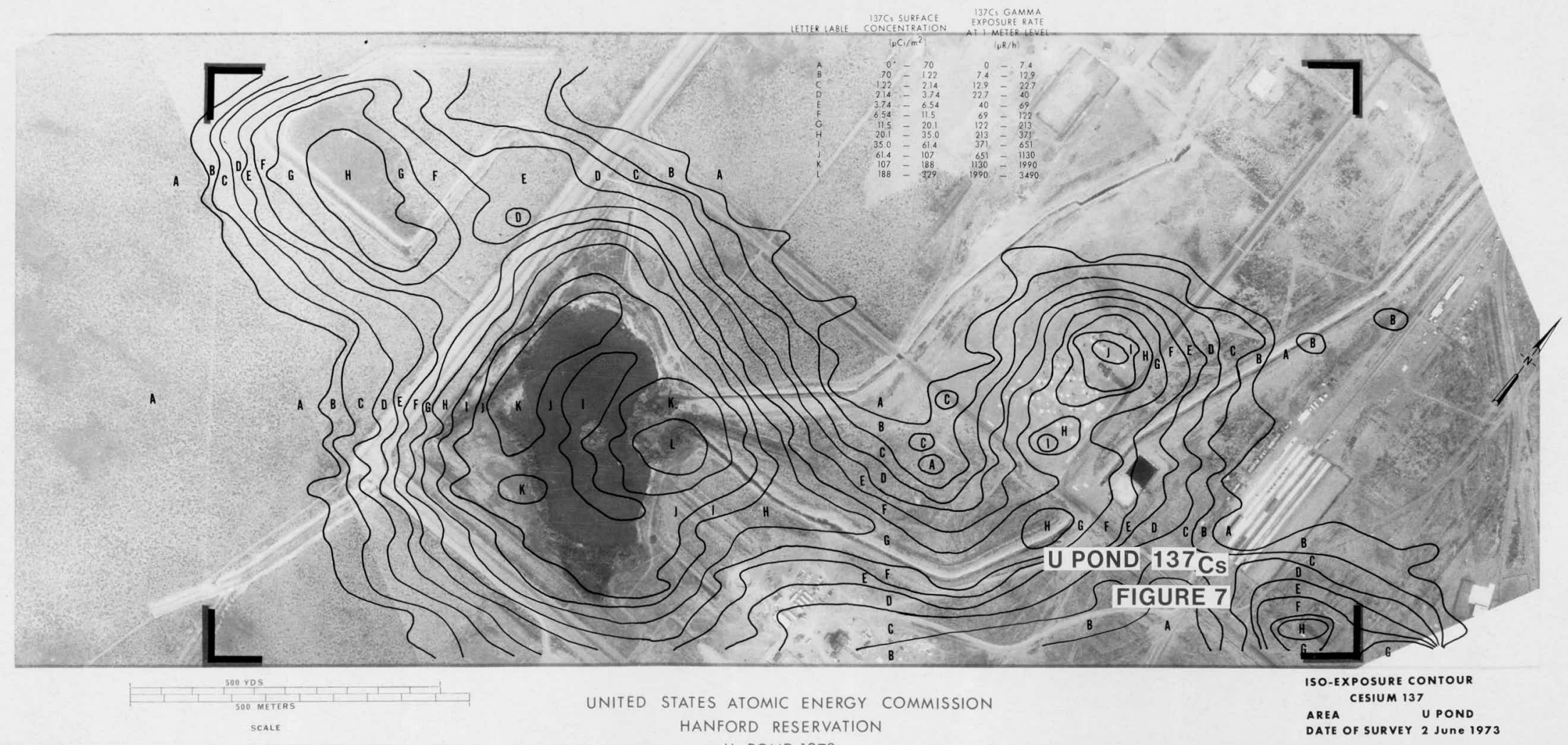

$$
\text { U POND } 1973
$$




$$
7421546
$$

\section{RAGLLAWD, WASHINGTOA}

99352 


\section{$\bullet$}

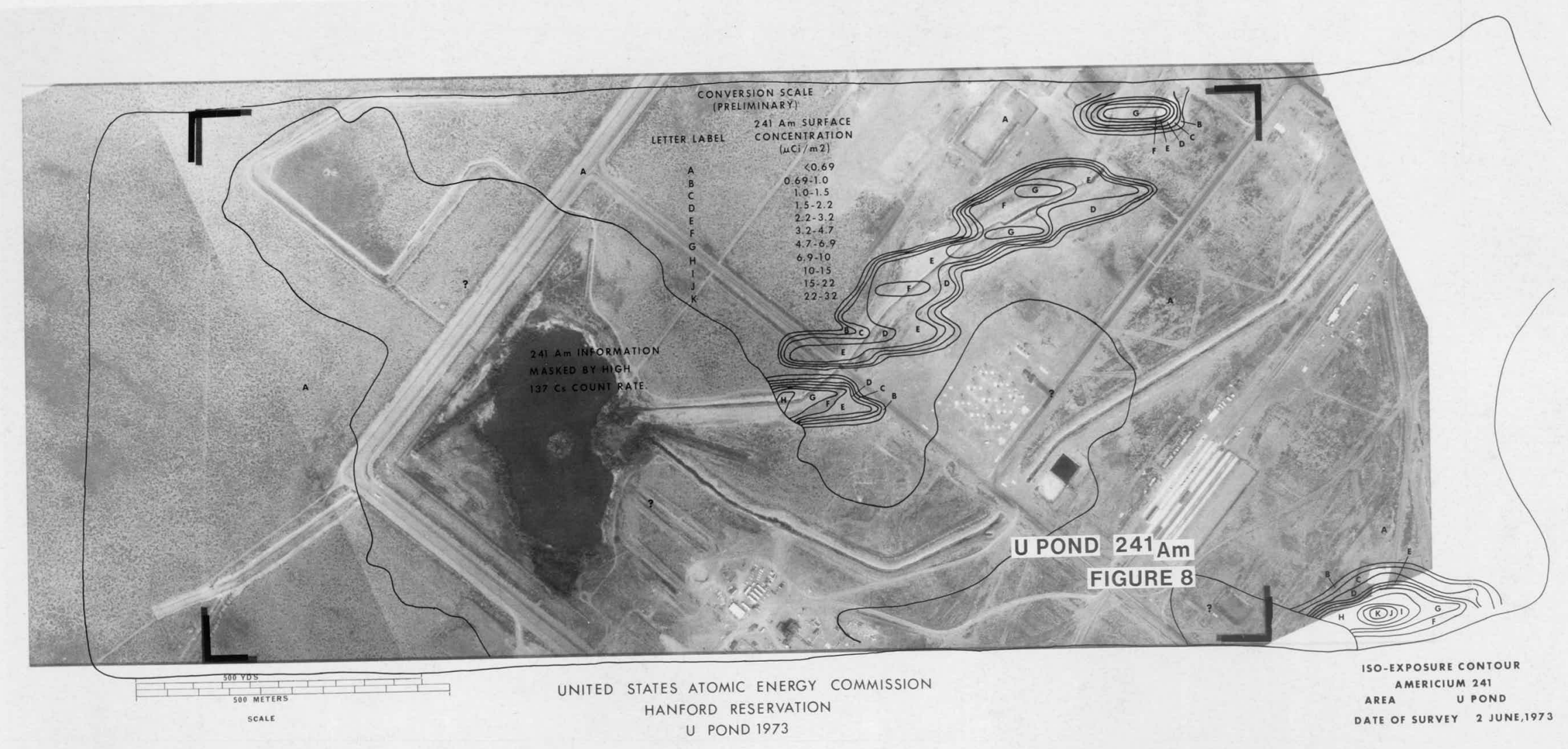




$$
\begin{aligned}
& \text { HIOTHD: } \quad 7421543 \\
& \text { BATTELLE-HORTHEST PHOTCaRAPUY } \\
& \text { RICHLAND, WASHAGTON } \\
& 99352
\end{aligned}
$$


